\title{
Reliability and Validity of the Disloyalty in the Workplace Scale
}

\author{
Huseyin Aslan ${ }^{1}$, Cevat Elma ${ }^{1} \&$ Yuksel Gunduz ${ }^{1}$ \\ ${ }^{1}$ College of Education, Ondokuz Mayis University, Samsun, Turkey \\ Correspondence: Cevat Elma, College of Education, Ondokuz Mayıs University, Atakum Samsun, Turkey. E-mail: \\ cevatelma@gmail.com
}

Received: September 10, 2019

Accepted: October 1, 2019

Online Published: October 3, 2019

doi:10.5430/ijhe.v8n6p100

URL: https://doi.org/10.5430/ijhe.v8n6p100

\begin{abstract}
The aim of this study is to develop a valid and reliable scale, which measures disloyalty in the workplace. The population of the study consisted of teachers working in the central area of Samsun in Turkey during 2017-2018 academic year. 742 teachers, who volunteered to take part in the study, constituted the sample of the study, and they were selected randomly. In data analysis process, exploratory factor analysis, confirmatory factor analysis and reliability analysis were used. According to the results of explanatory factor analysis, the scale was composed of 21 items and 2 sub-scales called manager disloyalty and colleague disloyalty and these two sub-dimensions have been explaining .86 .7 of total variance. According to the results of confirmatory factor analysis, all items constituted a meaningful structure under related factors and factor loadings of all items were above .30. As for the reliability analysis, Cronbach Alfa, Guttman and Spearman Brown analyses were carried out and Cronbach Alfa coefficient of total points of the scale was found as .99; the Guttman coefficient was found as .89 and Spearman Brown coefficient was found as .89 . This scale of which validity and reliability analysis were completed in this study can be used by researchers studying on disloyalty in the workplace as a data collection instrument.
\end{abstract}

Keywords: disloyalty, manager disloyalty, colleague disloyalty, teacher

\section{Introduction}

The world we live in can be defined as an organizational world. "Virtually all of us are born in an organization -a hospital- with our very existence ratified by a state agency that issues a certificate documenting our birth" (Pfeffer, 1997, p. 12). In this sense, we maintain all of our lives in for profit or non-profit organizations. Organization is a population of people working together in a division of labor to achieve a common purpose. This definition includes everything from clubs, voluntary organizations, and religious bodies to entities such as small and large businesses, labor unions, schools, hospitals, and government agencies (Shermerhorn, Hunt, Osborn \& Uhl-bien, 2010). Organizations differentiate in terms of their purposes, structures, resources, physical substructures, sizes, management style, etc. However, the key element of an organization is not a building or a set of policies and procedures but people and their relationships with one another. An organization exists when people interact with one another to perform essential functions that help to achieve goals. Recent trends in management recognize the importance of human resources designed to empower employees with greater opportunities to learn and contribute as they work together towards common goals (Daft, 2010, p. 11). It is the fact that employers or workers influence all the important aspects of organizational performance in one way or another. Employers conceive and implement the strategy. An organization's capabilities are involved in the mixture of its people and its systems (Lawler, 2006, p. 634). However, the distinctive element of the organization is the abilities and skills of the employees. As the abilities and skills provide advantages for the organization to compete, the organizations always must search the best ways of motivating the employees to use their abilities and skills (Jones, 2013)and this is the duty of the managers. As Başaran (2008) states, some basic needs of employees who contribute to achieve the goals of the organization with their labours should be met.

An organization's resource of energy is the individuals' willingness to make contributions to the common purpose. When the purpose of the organization can not be achieved at a satisfactory level, the willingness of individuals to make contributions to common purpose disappear and it means the disappearance of one of the vital elements for the existence of organization and it is life-threatening for the existence of the organization (Aydın, 2018). The organization provides status and work safety by employing an employee; the employee responds to it by showing a greater performance and avoiding tarnishing the organization's image (Schein, 1978). Equilibrium, one of the elements of 
organizational climate, is a relationship between the contribution that the individual makes to organization in a way of labor, skill and commitment and the response the organization gives in a way of payment, security and adoption. In other words, "equilibrium is the rate between the purposes of the organization and the importance given to the requirements of the individual" (Bursalığlu, 2015, p. 43). The individual's behavior in organization is generally discussed in terms of the reaction he/she demonstrated to the policy and process of organization (Aydın, 2018, p. 21). Benefitting from the manpower at an optimum level is possible with developing consistent and coherent policies for the worker. Thanks to these policies, the commitment of the worker to the organization and his/her performance increase. Looking after the employee and worker's common benefits is prerequisite for the success of an organization (Canman, 2000).

A manager should have the ability to impress the people around him/her and integrate them consciously to realize the aims beyond his/her expectations. Also, the manager should enable the workers to commit to the organization and motivate their energy for the purposes of organization in a coordinated way (Aydın, 2018, p. 273). This contributes to the emergence of healthy organizations. The institutions that have a healthy organizational climate can challenge with the environment successfully and use its sources to achieve its aims (Hoy \& Miskel, 2010, p. 189).

To enable the workers to work in an environment far from stress and have job satisfaction, creating an organizational climate providing these opportunities for them is necessary. This climate would contribute to the organizational efficiency as well as job satisfaction (Tutar, 2009). Not only the subordinate-senior relationships but the relationships among colleagues have vital importance in achieving the aims. Cooperation among colleagues is described as the support that colleagues give each other and sharing of knowledge, technique and skills within occupational context (Çoban, 2005, p. 168). Colleagues' helping each other (their cooperation) improves the workers' talents and skills by protecting the institution from the devastating and undesirable effects and increases the efficiency of the institution by establishing an effective coordination (Çetin, 2004). Communication among people has a vital role in establishing and maintaining human relations in workplace. A great deal of impediments that are included in an organization hamper the communication process (Bursalığlu, 2015). These internal and external impediments which hamper an effective and healthy communication process vary. In this sense, such impediments as filtering, selective perception, the content of the message, language that is used, emotions, cultural differences, personality, feedback, status differences, personal characteristics (gender, marital status, and educational background), needs and interests, environment, communication channel, size of the organization, etc can be given. One of the factors that cause the damage of communication, reduce the cooperation, helping and solidarity among colleagues in organizations is perception and feeling of disloyalty experienced by some individuals in the organization.

Disloyalty is one of the deep and complex phenomenon of the work life. Disloyalty is an emotional detachment behavior which manifests itself in both the relationships among subordinates and subordinates-seniors and has the capacity to affect the whole organization due to its behavioral results. That kind of an emotional detachment causes the feeling of mistrust to root in working relations and organizational climate.

Josephson (1992) regards the value (merit) of loyalty among such basic global values as honesty, keeping promise, justice, thought, respect towards others, responsibility, pursuit of perfection and accountability. The concept of loyalty which has Arabic origins etymologically is generally described as keeping promise, being loyal to the agreement. The concept of "ahde vefa" which is characterized as "Pacta sunt servanda" in Latin is the rule referring that the states have to adhere to the international agreements they took part according to the International Law (Turkish Language Institution [TDK], 2018). While 'loyalty' is defined as keeping promise, maintaining the friendship, commitment of love in the dictionary of Turkish Language Institution (2018); 'disloyalty' is defined as the condition of being impermanent in love.

Loyalty is an emotion that has value and meaning both individually and socially. It is also "the assurance that people have the sense of trust towards each other in public space (Çiftçi, 2015, s.74). The phenomenon of loyalty or disloyalty has utmost importance for not only daily life but working life as well. Loyalty-disloyalty is a phenomenon related to the basic elements of working life such as organizational citizenship, commitment, faithfulness and ethics to a great extent. However, this relationship is just observed in the results of that kind of a behavior. The behavior of organizational citizenship is one of the best examples of this situation. Organizational citizenship is generally defined as a voluntary type of behavior which is beyond the formal job definitions, going beyond the role requirements and expectations and contributing to the process of organization in an effective way (Allen \& Rush, 1998; Bateman \& Organ, 1983; Deery, Rayton, Walsh \& Kinnie, 2017; Organ, 1988; Organ, 2018; Podsakoff, Whiting, Podsakoff \& Blume, 2009; Robbins \& Judge, 2012). Beyond all job definitions extra role behaviors, willingness/volunteering is closely related to the perception of loyalty or disloyalty. Treatment that the worker experienced as a result of his/her 
acts such as support, effort, help, willingness, exhibiting extra role behaviors, etc, the behavior patterns of his/her managers or colleagues lay the groundwork for loyalty or disloyalty. After such kind of a realization, positive or negative changes are observed on the level of the organizational citizenship behaviors of the worker.

Taking the literature into account, it is identified that the loyalty or disloyalty is directly related to the value of faithfulness. According to Comte- Sponville (2004, p. 18-21) loyalty is not a value like other values and not a virtue like other virtues; loyalty is to remember the duty that does not time out; it is mercy and gratitude to the past. Loyalty is a golden standard which is used to measure the quality of a relationship. Real loyalty is based on the relationship types in the best and worst times and transforms mutual benefits into common goals (Reichheld, 2001, p. 5). ComteSponville (2004, p. 20) describes the relationship between faithfulness and disloyalty as following:

Loyalty is the opposite of dissolute and self-seeking inconstancy, denial, treachery, unfaithfulness not forgetting. However, what disloyalty arrives at last that loyalty resists against forgetting is true - as every virtue resists against the slope it is climbing: First what is remembered is betrayed, then what is betrayed is forgotten.

In this sense, disloyalty is being forgotten, not remembered and neglecting the help and favors. Sometimes, it is the condition of deliberate withdrawal. This is the acceptance of the condition that the individual to whom the feeling of loyalty was previously embraced does not need this loyalty anymore and the settlement of the behavior of communicating less as a result. Loyalty is not the reflection of the desire that is expected to be fulfilled by others. Instead, it is the desire to see the emergence of the expectations towards the continuity of others' previous behavior and attitudes. The expectation that "Become as you need me or behave so" does not overlap with disloyalty. That kind of an attitude and behavior reflect a deal that is based on mutual benefits. Therefore, the individual expressing about the disloyalty of his/her colleagues or managers does not act on the expectation of a response to his/her actions. He/she exerts his/her desire of being remembered; expecting that what they did must not be forgotten. This desire is mostly not made feel openly and expected from the opponent-side to remember spontaneously.

The existence of the feeling of disloyalty for a worker is influenced by the behavior patterns of their colleagues and managers. The perception of the worker that they do not see the value they deserve is reflected in his/her performance and relationships at work negatively. The perception of disloyalty may cause such important values in work life as trust, support, commitment, faithfulness, justice, respect, love, sympathy and self-sacrifice to be lost. Also, the relationship with the people who are thought to be disloyal differentiates. It gets difficult to reestablish healthy work life relationships. Perhaps, one of the most negative impacts of this situation on new employees is the direct or indirect transmission of the message including "whatever you do, you are not appreciated here" all around the institution. This situation not only creates negative effects on occupational and organizational socialization but it causes the organizational culture to disrupt.

The consequences of the disloyalty perception can be basically addressed in two levels: The first one is the consequences arising from the standpoint of the worker who thinks that he has been exposed to an injustice. The organizational belonging, moral and motivation of the worker who has the perception of disloyalty may decrease. The second one is the consequences arising from the attitudes and behaviors towards the people who are thought to be disloyal. This negatively affects the work relations, behaviors and attitudes toward the mutual trust, support and assistance to a great extent. In terms of organization, this situation pays the way for the deterioration of institutional climate. Encountering with a behavior and attitude which you could not expect from your friend causes the relationship between two friends to disrupt. In a real relationship, "every individual should want the success of relationship and maintenance of the relationship beyond their personal interests in short term" (Reichheld, 2001, p. 16).

Loyalty requires to make a promise mutually and once it's realized that these promises are not kept; loyalty decreases in some of the individuals who are broken, anger, distrust and disappointment emerges and this can cause infidelity, misappropriation and disloyalty (Connor, 2007). It is possible to assert that loyalty is a basic virtue, reality and disloyalty is the opposite of it. However, that kind of an assertion is incomplete. Because unfaithfulness, disloyalty in the specific sense is a more complex phenomenon (Keller, 2007, p. 201). Keller's (2007) example for this situation can make both faithfulness and disloyalty more clear.

Think about a student who is preparing a project under your supervision and made some progress in this project. Imagine that the student conveyed that he/she decided to experience a different project and study with a different supervisor for the sake of his/her own interest and career. If you spent a lot of time with his/her project as his/her first supervisor and attempted to finance and supervise the project, you would feel disappointed when he/she told that he/she wanted to study with another supervisor. However, you can understand the student's discontinuation to the project you assigned just to show his/her trust and belief towards you. In this sense, in spite of all efforts, the 
student's tending to a different project is disloyalty. But if the project the student tended to later is the best for his/her, what should the student do in this sense? (p. 203).

The complexity of the concept of disloyalty brings a number of problems with it. What is required to characterize a behavior as disloyal? What criteria would be used to determine it? In which occasions could we say that disloyalty was experienced? If one asserts that he/she experienced disloyalty, how can they provide justification? Loyalty- disloyalty take place among the concepts whose affective aspect outweighs. Thus defining and describing the feeling of disloyalty requires a number of conditions. Firstly, disloyalty does not arise because of not deriving personal benefit. It is not the satisfaction of the expectation of benefit. Secondly, charging somebody sentimentally on account of the action in your own job definitions is not to expect him/her loyalty. The actions of the worker within extra role behaviors have vital importance in experiencing the feeling of disloyalty. It is the basic responsibility of the worker to perform a duty in the required quality and quantity. However, each additional contribution the worker provided to the culture, climate, productivity, solidarity and cooperation among workers requires his being appreciated, remembered, valued and supported. If the attitudes and behaviors of the manager or colleagues do not include these, it causes the worker to experience the feeling of disloyalty. Characterizing a manager or colleague as disloyal is the result of forgetting, ignoring and not remembering of what the person did. Even, the worker who thinks that they are exposed to disloyalty bemoans, reproaches and sometimes reveal his/her anger against the attitudes and behaviors of his/her manager and colleagues. That kind of a situation causes the change of worker's point of view towards the organization, a decrease in his/her job satisfaction level and motivation and his/her being demoralized. The basic duty of the manager is to motivate the workers' cognitive, sensual and behavioral powers to achieve the goals. For this reason, valuing, appreciating and remembering the workers who make effort and exhibit performance at a high level beyond the standards determined should be accepted as an obligation.

There is a limited number of studies about loyalty-disloyalty in the literature. Any other studies but carried out by Yeğin (2017) have not been found in Turkey. In the culture which we live, the feeling of loyalty is given great importance. However, this significance does not manifest itself in scientific studies and a hesitation to make researches about this issue is seen and this may be stem from the difficulty of making an operational definition of the concept. Not discussing and making researches about the influence of this phenomenon which is especially felt in work life is regarded as important. The concept's itself being inexplicit and unclear largely affects this situation. So as to make the concept more clear and explicit and introduce the basic perspective in this study, what loyalty and disloyalty refers to in work life is explained in the following figure (Figure 1).

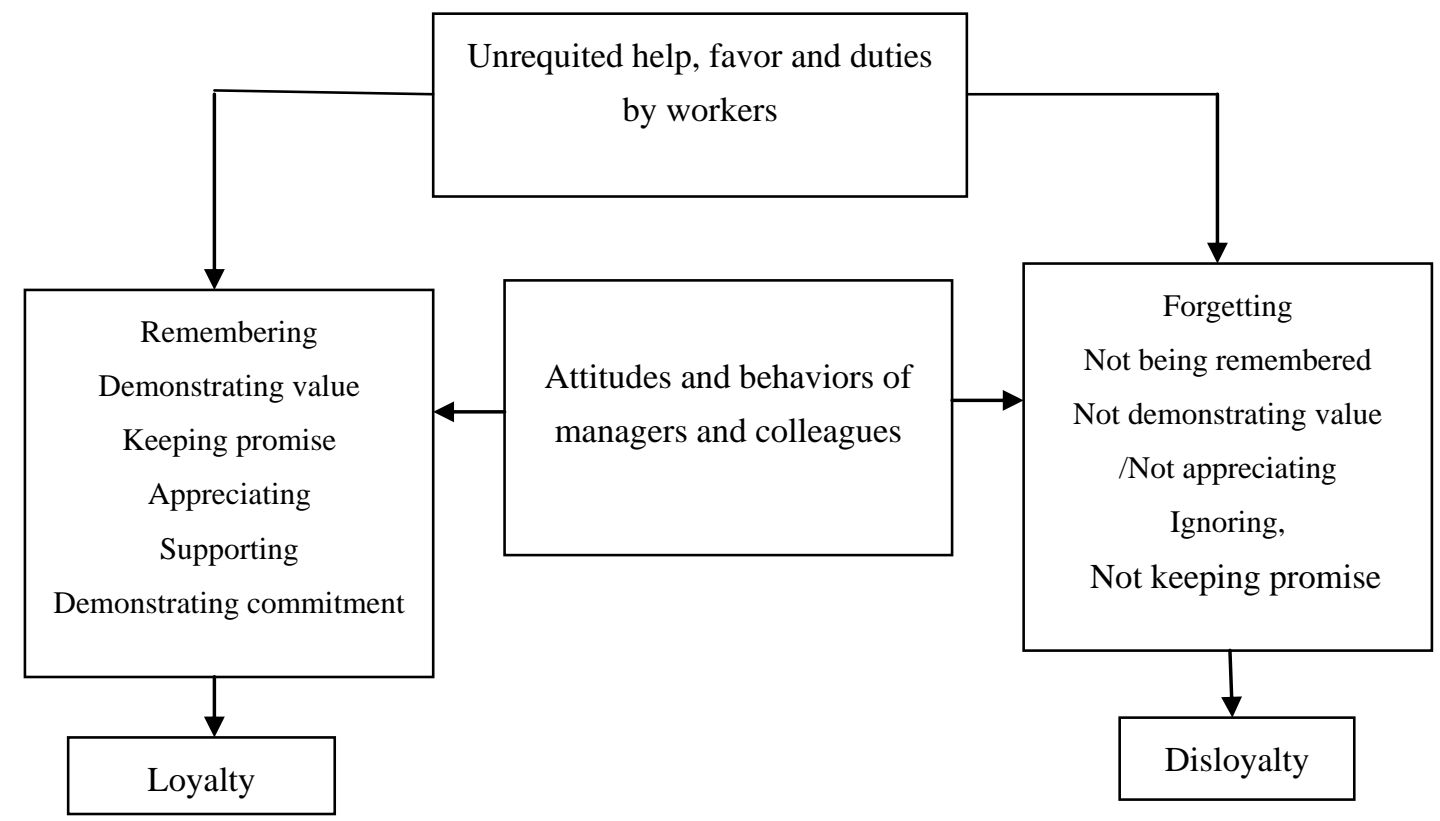

Figure 1. Loyalty-disloyalty diagram

Because of the reasons stated above, work life disloyalty is described as the emotional detachment which is caused by not remembering, not valuing, not appreciating, forgetting and ignoring the worker's helps to others (within ethical 
boundaries), support he gave, solidarity, guidance, extra role behaviors he demonstrated in the work environment. As disloyalty may cause more problems in the process of organization and organizational relationships, it is believed that the study will contribute to the related literature.

\subsection{Purpose of the Research}

The aim of this research is to develop a valid and reliable scale to determine the opinions of the teachers about disloyalty in the workplace. Disloyalty in the workplace scale can be used to determine the opinions and attitudes of teachers towards their workplaces and predict the behaviors and attitudes by correlating with other organizational variables. This scale can be used to determine the disloyalty perceptions of the teachers either working in public or private.

\section{Methods}

This research that aims to develop a valid and reliable "Disloyalty in the Workplace" scale is carried out with survey method. The population of this research included teachers working in schools (preschool, primary, secondary, high school), during 2017-2018 academic year and 742 teachers working at these schools and determined with random sampling method constituted the sample of the research. There are various opinions about the ideal sample size in scale development studies. While Pedhazur (1997) accepts a sample of 10-15 for each item as ideal, Nunnaly (1978) asserts that a sample of 10 for each item is enough. It is evident that this research meets the sample size criteria accepted for the scale development studies. As for the characteristics of sample, it's revealed that out of 742 teachers, 59.8\% of them are women; $40.2 \%$ are men. $74.5 \%$ of the sample are married; $25.5 \%$ of them are single. The sample also includes $22.4 \%$ of teachers who have 16-20 years teaching experience, $22.4 \%$ of teachers who have $11-15$ years teaching experience, $20.4 \%$ of teachers who have 1-5 years teaching experience, $19,9 \%$ of teachers who have; 21 or more years of experience and $16.4 \%$ of teachers who have 6-10 years teaching experience. Lastly, the teachers $41.5 \%$ of teachers work in primary schools, $19.5 \%$ of them work in secondary schools, $32.7 \%$ of them work in high schools and $6.2 \%$ of them work in pre-schools.

As data collection instrument, a form including demographic information of the teachers (such as gender, marital status, and professional seniority) and disloyalty in the workplace scale were used. Before developing the "Disloyalty in the workplace Scale", literature regarding the concept of loyalty and disloyalty was searched in detail and basic subheadings required to be included in this study were determined. Later, an item pool of 38 items was made up by writing the statements regarding the workplace disloyalty perceived by teachers under these subheadings. The items in the item pool were submitted to three academics studying in the field of educational administration for their opinions and some items were deleted or edited accordingly. Lastly, "Disloyalty in the workplace Scale" included 21 items. Also, the scale was submitted to the opinions of two Turkish teachers to test the clarity and intelligibility of the items. It is a 5 point Likert -rating scale on frequency of activity, ranging from 1 representing 'never' to 5 'Always'. All items of the scale have positive scores. The participants were informed about the requirements while responding to the scale. The replies of the participants were transferred to the computer and those scale forms which are filled in mistakenly or not filled at all were not taken into evaluation process. . After the completion of data entry, firstly frequency analysis was carried out and the data mistakenly entered were scanned. Later, frequency and percentage rates of the data were found and explanatory factor analysis was carried out with varimax rotated method. The value of minimum Eigen value was accepted as "1". While deciding on the factor numbers of scale, the total variance percentage explained by factors and the graphic of scree plot were selected as the baseline. After determining the sub-dimensions, factors, factor loadings of items under each sub dimension, item total correlation coefficients were calculated. To test the structure validity of the scale with a different method, correlation coefficients between total points and sub-dimensions were also calculated. After deciding that Explanatory Factor Analysis deliver healthy results, confirmatory factor analysis was performed. At the last phase of the research, the reliability of each sub-dimension and total scale was determined with internal consistency coefficients.

Within the research, all results were predicted bidirectional and meaningfulness level was accepted at least as .05. Also, meaningful results on the levels of .01 and .001 were taken into account. All of the analysis of the research was performed with SPSS for Windows and LISREL.

\section{Results}

In this part of the study, development process of this scale, results of explanatory and confirmatory factor analysis and reliability analysis are given in a detailed way. 


\subsection{Structure Validity}

Structure validity of a scale may be tested by various methods and the first of these methods is factor analysis. Factor analysis can be classified as Explanatory Factor Analysis (EFA) and Confirmatory Factor Analysis (DFA) (Şencan, 2005). In this study, firstly Explanatory Factor Analysis and then Confirmatory Factor Analysis are carried out. Prior to Explanatory Factor Analysis, Kaiser-Meyer-Olkin (KMO) and Barlett tests were performed so as to test the adequacy and relevance of the sample size to factor analysis. The coefficient of Kaiser-Meyer-Olkin (KMO) was found as .976 . Relevance of the sample size to factor analysis is possible with the coefficient of KMO over .60 in scientific studies. As the KMO coefficient in this study is over .60, the sample size is decided to be adequate. As for Barlett sphericity test results, it was determined that results $\left(\mathrm{X}^{2}(210)=26553.590 ; \mathrm{p}<.001\right)$ are meaningful and factor analysis can be carried out.

\subsection{Explanatory Factor Analysis (EFA)}

As factorization technique, maximum variability (varimax) was used. In explanatory factor analysis, common factor variance of each item must be at least .50. After maximum variability (varimax) analysis which is performed with 21 items of the scale, it was determined that the scale consists of two sub dimensions whose eigen value is over 1. The eigen value of the first factor is 9.40 and it explains 44.78 of total variance. The eigen value of the second factor is 8.83 and it explains 42.04 of total variance. The percentage of total variance which two factors explained together was found as 86.82 .

Table 1. Explanatory factor analysis results of disloyalty in the workplace scale

\begin{tabular}{|c|c|c|c|c|c|}
\hline \multirow[t]{2}{*}{ Items } & & & $\begin{array}{c}\text { Common Factor } \\
\text { Variance }\end{array}$ & $\begin{array}{l}\text { Item-Total } \\
\text { correlation }\end{array}$ & $\begin{array}{c}\text { Item-Total correlation } \\
\text { (related } \\
\text { sub-dimensions) }\end{array}$ \\
\hline & Factor 1 & Factor 2 & & & \\
\hline I1 & .26 & .87 & .82 & .77 & .86 \\
\hline $\mathrm{I} 2$ & .37 & .86 & .88 & .85 & .92 \\
\hline $\mathrm{I} 3$ & .36 & .87 & .89 & .85 & .92 \\
\hline I4 & .38 & .87 & .90 & .86 & .93 \\
\hline I5 & .40 & .85 & .88 & .86 & .92 \\
\hline I6 & .41 & .86 & .916 & .88 & .94 \\
\hline I7 & .43 & .81 & .84 & .86 & .90 \\
\hline I8 & .40 & .85 & .88 & .866 & .92 \\
\hline I9 & .49 & .76 & .82 & .87 & .88 \\
\hline $\mathrm{I} 10$ & .48 & .75 & .79 & .85 & .86 \\
\hline $\mathrm{I} 11$ & .73 & .45 & .74 & .829 & .83 \\
\hline $\mathrm{I} 12$ & .81 & .45 & .86 & .88 & .91 \\
\hline $\mathrm{I} 13$ & .81 & .47 & .87 & .90 & .92 \\
\hline $\mathrm{I} 14$ & .79 & .46 & .84 & .88 & .90 \\
\hline $\mathrm{I} 15$ & .85 & .40 & .89 & .88 & .93 \\
\hline $\mathrm{I} 16$ & .84 & .42 & .90 & .89 & .93 \\
\hline $\mathrm{I} 17$ & .88 & .37 & .91 & .88 & .94 \\
\hline $\mathrm{I} 18$ & .86 & .32 & .84 & .83 & .89 \\
\hline I19 & .88 & .38 & .92 & .88 & .94 \\
\hline $\mathrm{I} 20$ & .86 & .32 & .86 & .83 & .90 \\
\hline $\mathrm{I} 21$ & .88 & .32 & .88 & .84 & .91 \\
\hline
\end{tabular}

According to Büyüköztürk (2019), if there is a group of items which has a high level of relationship with one factor, it means that these items altogether measure and explain a concept-structure. So, factor load value 0.40 or over is 
accepted as an adequate measure. As can be seen in Table 1, factor loadings of the items included in a factor are mostly over .50. While factor loadings in the first factor ranges from maximum .88 to minimum .73 ; it ranges from .88 to .75 . Scree plot graphic which is used to determine the factor structure of 21 items in the scale is given as following:

\section{Scree Plot}

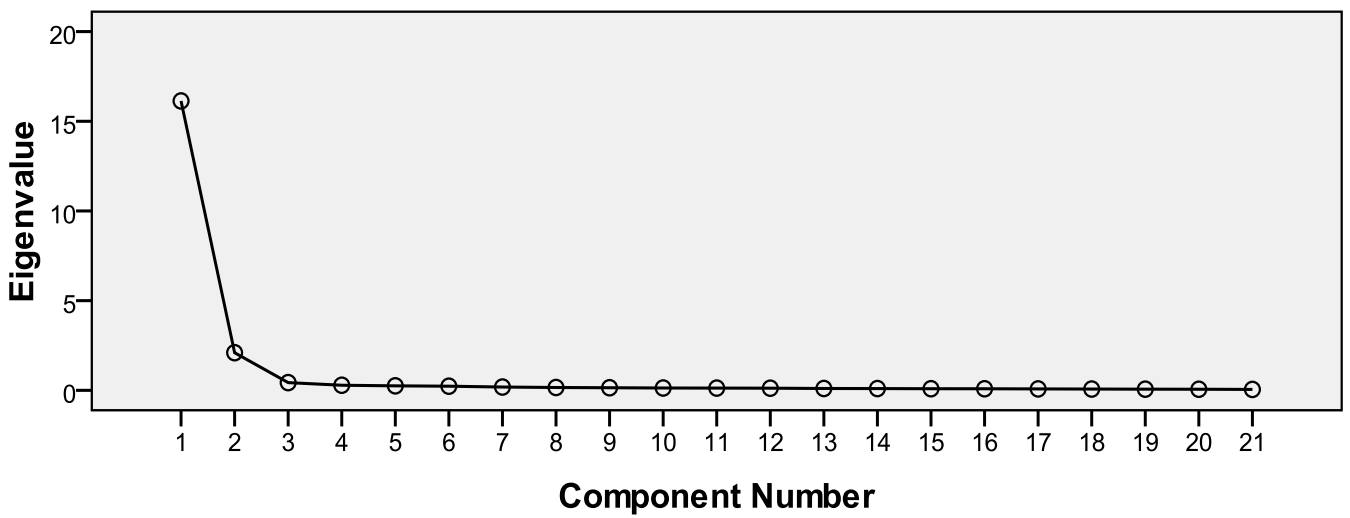

Figure 2. Scree plot

Taking the scree plot graphic into consideration, it is clearly seen that the scale has two different dimensions. It is important to calculate common factor variance in multi-factor patterns. So, common factor variances of each item was calculated in this research. Accordingly, the lowest value of common factor variances was found as .74. Factor variances' being higher than .20 indicates that there is homogeneity among variances. Taking the content of the items included in two sub dimensions which revealed as a result of the explanatory factor analysis, the first factor was called as Colleague Disloyalty and the second one was called as Manager Disloyalty.

\subsection{Confirmatory Factor Analysis (CFA)}

To test the validity of the factor structure emerging as a result of explanatory factor analysis, confirmatory factor analysis was carried out with LISREL 8.80 statistics program. So as to evaluate the model, firstly the meaningfulness of t-values of each item which ranks under the factors was examined. As a result of this evaluation, it was observed that all items are meaningful under related factors. Secondly, standard factor load values of items were examined and it was identified that the requirement that standard factor load values have to be over 30 was met. Lastly, model fit indexes were examined and fit index values regarding model-data fit were shown in Table 2. As a result of confirmatory factor analysis path diagram, goodness of fit values has been obtained and these findings are interpreted. For the models which are attempted to confirm as a result of data analysis, $\chi 2 / \mathrm{df}$, RMSEA ve CFI, GFI, AGFI, SRMR and NNFI have been used as statistical fit indexes.

Table 2. Goodness of fit values obtained by the results of confirmatory factor analysis

\begin{tabular}{ccccccccccc}
\hline Scale & $\kappa 2$ & $S d$ & $\times 2 / s d$ & $P$ & AGFI & GFI & CFI & NNFI & SRMR & RMSEA \\
\hline & 1974.70 & 188 & 1.96 & .000 & .75 & .80 & .98 & .98 & .04 & .0113 \\
\hline
\end{tabular}

At the end of the analysis. ratio of theoretical square value to the degree of freedom $(\mathrm{k} 2 / \mathrm{sd})$ was examined. The accepted value of this ratio must be $\times 2 / \mathrm{sd} \leq 5$ (Kline, 2005). In this analysis, it is seen that this value is below the breakpoint. $(\kappa 2 / \mathrm{sd}=1.96)$. Thus, it can be asserted that the model fit well. Taking RMSEA, one of the fit indexes, into consideration, the value of 0.01 which is accepted as quite well was obtained. While RMSEA value below .05 indicates perfect fit and .08 indicates good fit (Joreskob \& Sorbom, 1993), its being below .10 indicates weak fit. In this sense, the fit index obtained in this research indicates that there is a very good fit between the data and model. Also, when examined other fit indexes (AGFI, GFI, NFI and SRMR), it is seen that the values obtained are on acceptable level. Fit indexes presented at Table 2 and Figure 3 determines that the data obtained indicate good fitness with two-dimensional model. 


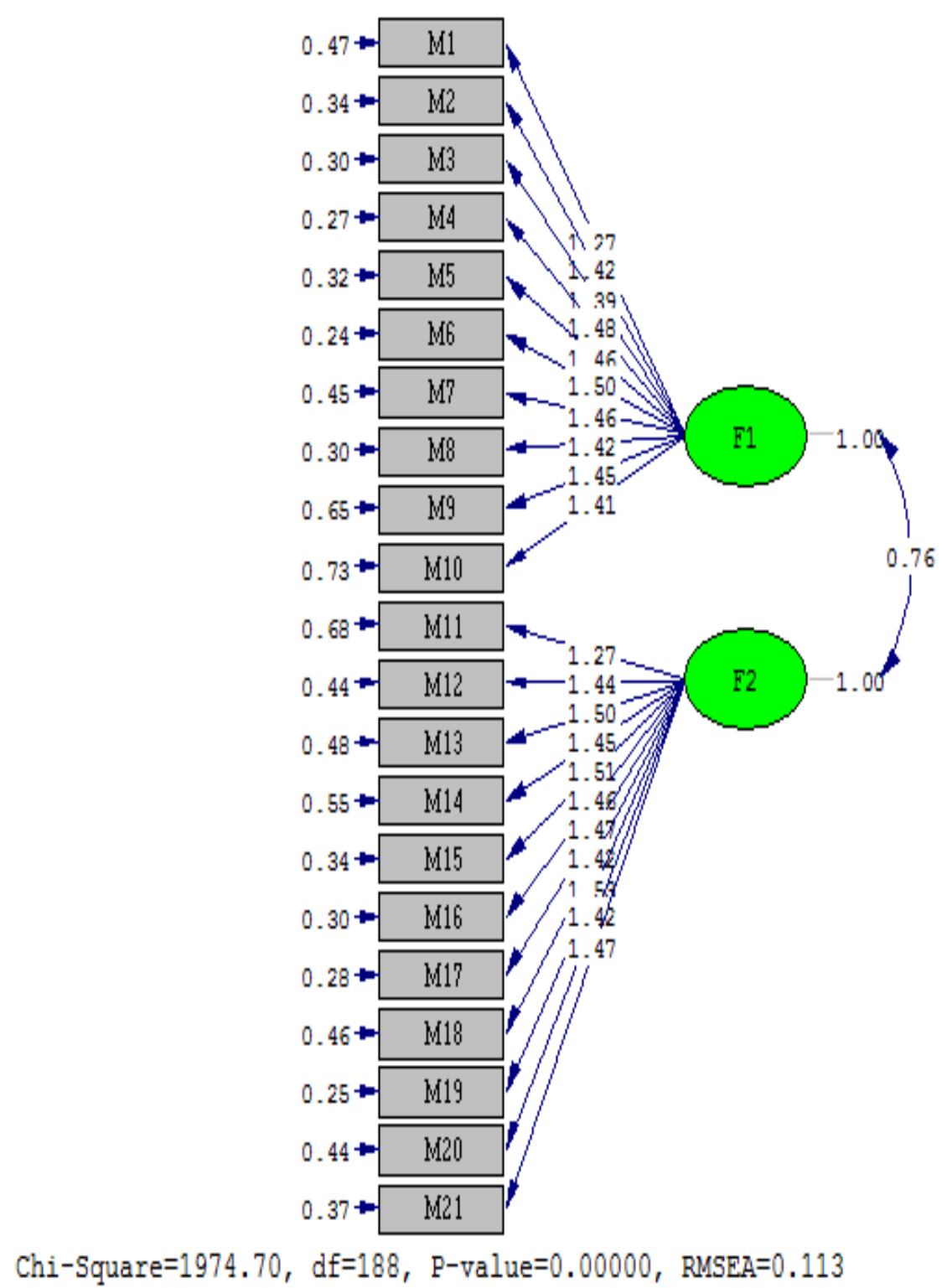

Figure 3. Path diagram regarding confirmatory factor analysis of the scale.

Another method to determine the structure validity of a scale is the investigation of the relationship between total points and the relationships between sub dimensions. In a valid test, it is expected that the relationship between all sub dimensions with test total points is statistically meaningful and high (Table 3).

Table 3. The relationship between disloyalty in the workplace scale and its sub-dimensions

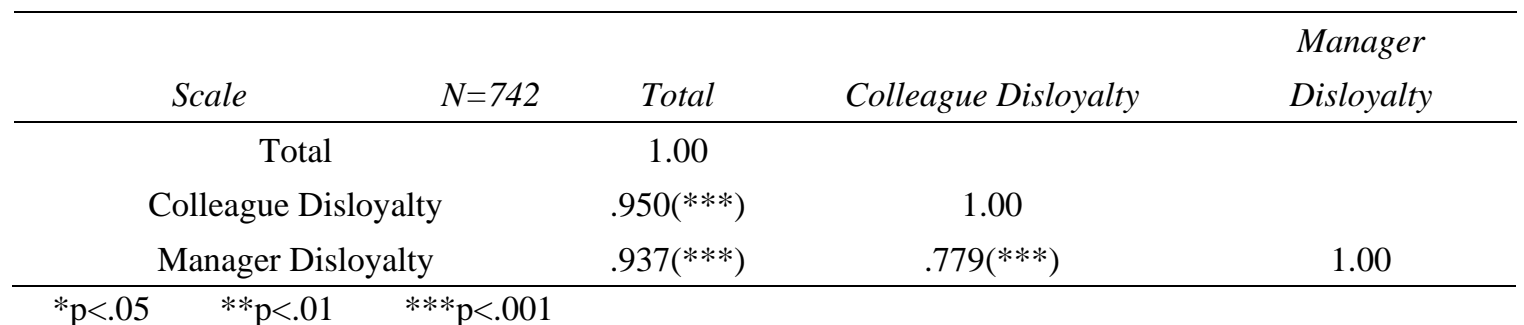


As shown in Table 3, it is revealed that there is a statistically meaningful relationship between total points of Workplace Disloyalty Scale and its sub dimensions as a whole. While the highest correlation is found in the dimension of "Colleague Disloyalty" with a mean of .950; the lowest correlation is found in the dimension of "Manager Disloyalty" with a mean of .937. It is also expected that in a valid test, the correlation coefficients between the sub dimensions are statistically meaningful; however, it's expected that correlations are on average or below average. The correlation coefficient between the dimension of "Colleague Disloyalty" and "Manager Disloyalty" has been found as .779 $(\mathrm{p}<.001)$.

\subsection{Reliability Analysis}

For the reliability analysis of "Disloyalty in the Workplace Scale", the whole scale itself and its internal consistency coefficient values are examined. Cronbach Alfa which is calculated based on the variance of each item and Guttman and Spearman Brown which is based on the cut of the scale into equal halves were used. These values are shown in Table 4.

Table 4. Internal consistency coefficients regarding the reliability of disloyalty in the workplace scale

\begin{tabular}{cccc}
\hline Scale & $\begin{array}{c}\text { Cronbach's } \\
\text { Alpha }\end{array}$ & $\begin{array}{c}\text { Guttman } \\
\text { Split Half }\end{array}$ & $\begin{array}{c}\text { Spearman } \\
\text { Brown }\end{array}$ \\
\hline Colleaugue Disloyalty & .98 & .97 & .97 \\
Manager Disloyalty & .98 & .97 & .97 \\
Total & .99 & .89 & .89 \\
\hline
\end{tabular}

Results regarding the reliability of "Disloyalty in the Workplace Scale" ranges from maximum .985 and minimum .887. Results regarding the reliability of the 'Colleague Disloyalty' dimension of the scale range from maximum .984 to minimum .965. Results regarding the reliability of the 'Manager Disloyalty' dimension of the scale range from maximum .982 to minimum .968. As all of these results are over 70, it has been identified that the scale and its sub dimensions have a high level of reliability.

It is not enough to examine just the total points and sub-dimension total points to make a scale both valid and reliable. It is also necessary that each item in the scale should be valid and reliable. For this aim, the value of each item should be in statistically meaningful relationships with both total scale points and sub-dimension total points. These values are accepted as the validity and reliability coefficients of the items. These analyses were performed within the context of this research and the results are presented in the table of Explanatory Factor Analysis. The 13th item has the highest correlation $(.900 \mathrm{p}<, 001)$. The correlation between item 28 and total points is. 77 and the lowest; however, this value is statistically meaningful on .001 level.

The item total correlations range from .94 (19th item) to .83 (11th item) in the first factor, "Colleague Disloyalty". The same values range from .93 (4th item) to .86 (1 th item) in the second factor, Manager Disloyalty. All of these results are statistically meaningful on .001 level. These results demonstrate that all of the items in "Disloyalty in the workplace Scale" are valid and reliable in both total scale and sub-dimensions.

\section{Discussion}

In this research which aims to develop "Disloyalty in the Workplace Scale", the validity and reliability analysis results of the scale were determined. Taking the related literature into account, it's identified that there is not such kind of a scale aiming to measure loyalty or disloyalty at workplace. It's just revealed that Yeğin (2017) developed a scale to identify loyalty levels of university students in terms of various variables and the sub dimensions of the so-called scale were identified as believing in loyalty, keeping promise, being loyal to relatives and friends, loyalty to the citizenship values, loyalty to national values, being honest and loyalty. Thus, it has been thought that there is a requirement to develop a valid and reliable scale determining disloyalty in the workplace. Accordingly, "Disloyalty in the Workplace Scale" including 21 items regarding working life has been prepared and applied to 742 participants and the data gathered were analyzed.

In the validity analysis of the scale, firstly construct validity was examined. As a result of the explanatory factor analysis, the scale including 21 items was determined to have 2 sub dimensions whose eigen value is over 1 . The eigen value of the first factor is found as 9.40 and it explains $44.78 \%$ of total variance. The eigen value of the second factor is 8.83 and it explains $42.04 \%$ of total variance. The scale with its two sub-dimensions explains $86.82 \%$ of total variance. Taking the content of the sub dimensions into account, the first factor was called as "Colleague Disloyalty" and "Manager Disloyalty". Thus it can be asserted that the scale has high construct validity. 
As for the results of the confirmatory factor analysis, it was revealed that all items are meaningful under related factors and standard factor loadings of all items are over .30. As a result of the confirmatory factor analysis path diagram, and goodness of fit measures were obtained and these findings were interpreted. As a result of the data analysis, for the models which are attempted to confirm $\chi 2$ /df, RMSEA ve CFI, GFI, AGFI, SRMR and NNFI were used as statistical fit measures. At the end of the analysis, it was identified that the value of $\chi 2 / \mathrm{df}$ is below the breakpoint. $(\mathrm{k} 2 / \mathrm{sd}=1.96)$. Thus, it is seen that the model indicates good fit. In the analysis, RMSEA, one of the fit indexes, obtained the values of 0,01 which is accepted as very good. Within this context, fit index obtained in this research indicates that there is a good fit between the data and model. Also, the values obtained by other fit indexes (AGFI, GFI, NFI ve SRMR) are on acceptable level.

Internal consistency of the scale and its sub-dimensions was determined through Cronbach's Alpha which is based on the variance of each item and Guttman and Spearman Brown Test based on splitting of scale items into two. Accordingly, coefficient of total points of scale was found as .99 for Cronbach's Alfa, .89 (Guttman) and .89 for Spearman Brown. Internal consistency coefficients in the first and second dimensions of the scale was found as .98 for Cronbach's Alpha and .97 for Guttman and Spearman Brown.

Results regarding the reliability of Disloyalty in the workplace Scale" range from maximum .98 to minimum .88. As all of these results are above .70, it can be asserted that the scale and its sub dimensions have a high level of reliability. All of the results regarding "Disloyalty in the Workplace Scale" is a valid and reliable data collection instrument. With this scale whose validity and reliability is proved, the perceptions of workers working in all organizations can be examined.

\section{References}

Allen, T. D. \& Rush, M. C. (1998). The effects of organizational citizenship behavior onperformance judgements: A field study and a laboratory experiment. Journal of Applied Psychology, 83, 247-260. http://dx.doi.org/10.1037/0021-9010.83.2.247

Aydin, M. (2018). Egitim yonetimi (11. Baski). Ankara: Gazi Kitabevi.

Basaran, I. E. (2008). Orgütsel davranıs: Insanın uretim gucu. Ankara: Siyasal Kitabevi.

Bateman, T. S. \& Organ, D. W. (1983). Job Satisfaction and the good soldier: The relationship between affect and employee"citizenship". Academy of Management, 26(4), 587-595. http://dx.doi.org/10.2307/255908

Bursalıglu, Z. (2015). Okul yonetiminde yeni yapi ve davranis (19. Baski). Ankara: Pegem Akademi.

Buyukozturk, Ş. (2019). Sosyal bilimler icin veri analizi el kitabi (25. Baski). Ankara: Pegem Akademi. https://doi.org/10.14527/9789756802748

Canman, D. (2000). Insan kaynaklari yonetimi, Ankara: Yarg1 Yayınevi.

Comte- Sponville, A. (2004). Buyuk erdemler risalesi (Çev. I. Ergüden). İstanbul: Bilgi Üniversitesi Yayınları.

Connor, J. (2007). The sociology of loyalty. Canberra, Australia: Springer Science Business Media.

Cetin, M. Ö. (2004). Orgutsel vatandaslik davranisi. Ankara: Nobel Yayın Dağıtım.

Ciftci, H. (2015). Siyaset kulturumuzde ahde vefâ ve nakz-i ahd. Cankırı Karatekin Universitesi Sosyal Bilimler Enstitüsü Dergisi, 6(1), 073-084. http://sbedergi.karatekin.edu.tr/DergiTamDetay.aspx?ID=215\&Detay=Ozet

Coban, A. E. (2005). Psikolojik danismanlar icin meslektas dayanısmasi. Mersin Üniversitesi Egitim Fakültesi Dergisi, 1(1), 167-174.

Daft, R. L. (2010). Organization theory and design (10th Edition). Mason: South-Western Cengage Learning.

Deery, S. Rayton, B. Walsh, J. \& Kinnie, N. (2017). The costs of exhibiting organizational citizenship behavior. Human Resource Management, 56(6), 1039-1049, https://doi.org/10.1002/hrm.21815

Hoy, W. K. \& Miskel, C. G. (2010). Egitim yonetimi. Ankara: Nobel Yayin Dağitim.

Jones, G. R. (2013). Organizational theory, design and change (7th Edition). Boston, MA: Pearson Education.

Joreskob, K. G. \& Sorbom, D. (1993). LISREL 8: Structural equation modeling with the SIMPLIS command language. London: Lawrence Erlbaum Associates Publishers.

Josephson, M. W. (1992). The need for ethics education in accounting. S. Albrecht (Ed.), Ethical Issues in the Practice of Accounting (s.1-20). Cincinnati, Ohio: Southwestern Publishing Co.

Keller, S. (2007). The limits of loyalty. New York: Cambridge University Press. 
Kline, R. B. (2005). Principles and practices of structural equation modeling. New York: Guilford Press.

Lawler, E. E. (2006). What makes people effective? Gallos, J. V. (Ed.). Organization Development. San Francisco: John Wiley \& Sons, Inc.

Pfeffer, J. (1997). New directions for organization theory: Problems and prospects. Oxford: Oxford University Press.

Podsakoff, N. P. Whiting, S. W. Podsakoff, P. M. \& Blume, B. D. (2009). Individual-and organizational-level consequences of organizational citizenship behaviors: A meta-analysis. Journal of Applied Psychology, 94(1), 122-141, http://dx.doi.org/10.1037/ a0013079

Nunnally, J. C. (1978). Psychometric theory (2nd ed.). New York: McGraw Hill.

Organ, D. W. (1988). Organizational citizenship behavior: The good soldier syndrome. Lexington Books, Lexington: MA.

Organ, D. W. (2018). The roots of organizational citizenship behavior. Podsakoff,P. MacKenzie, S. B. \& Podsakoff, N. P. (Ed.). The Oxford Handbook of Organizational Citizenship Behavior, 7-18. New York: Oxford University Press.

Pedhazur, E. J. (1997). Multiple regression in behavioral research: Explanation and prediction. Fort Worth: Harcourt Brace College Publishers.

Reichheld, F. F. (2001). Loyalty Rules: How today's leaders build lasting relationships. Boston, Massachusetts: Harvard Business School Press.

Robbins, S. \& Judge, A. T. (2012). Orgutsel davranıs. (Çev. Ed. İ. Erdem) Ankara: Nobel Akademi Yayincilik.

Schein, E. H. (1978). Orgut psikolojisi. (Cev. M. Tosun). Ankara: Turkiye ve Orta Dogu Amme Idaresi Enstitusu.

Shermerhorn, J. R., Hunt, J. G., Osborn, R. N. \& Uhl-bien, M. (2010). Organization behaviour (11th Edition). San Francisco: John Wiley \& Sons, Inc.

Sencan, R. (2005). Sosyal ve davranissal olcumlerde guvenirlik ve gecerlik. Ankara: Seckin Yayınevi.

TDK. (2018). Genel Turkce sozluk. http://www.tdk.gov.tr.

Tutar, H. (2009). Orgutsel iletisim. Ankara: Seçkin Yayıncılık.

Yegin, H. İ. (2017). Vefakârlik ölçeğinin gecerlik ve güvenirlik calısmasi. Abant Izzet Baysal Universitesi Ilahiyat Fakultesi Dergisi, 5(9), 119-132, https://dergipark.org.tr/tr/download/article-file/322909 


\section{Workplace Disloyalty Scale}

\begin{tabular}{|c|c|c|c|c|c|c|}
\hline & & Never & Rarely & Sometimes & Often & $\begin{array}{l}\text { Very } \\
\text { Often }\end{array}$ \\
\hline 1 & My manager ignores sacrifices. & & & & & \\
\hline 2 & $\begin{array}{l}\text { My manager acts as if I did not do anything, though I } \\
\text { complete the tasks he gives me in the best possible way. }\end{array}$ & & & & & \\
\hline 3 & $\begin{array}{l}\text { My manager ignores the ones who put more effort into } \\
\text { work than their peers do. }\end{array}$ & & & & & \\
\hline 4 & My manager disregards previous accomplishments. & & & & & \\
\hline 5 & My manager does not appreciate achievements. & & & & & \\
\hline 6 & $\begin{array}{l}\text { My manager does not value the assistance and services } \\
\text { provided. }\end{array}$ & & & & & \\
\hline 7 & $\begin{array}{l}\text { My manager makes a big deal out of successful } \\
\text { employees' small flaws. }\end{array}$ & & & & & \\
\hline 8 & My manager ignores extra efforts and endeavors. & & & & & \\
\hline 9 & $\begin{array}{l}\text { My manager is uninterested in the health problems of } \\
\text { employees. }\end{array}$ & & & & & \\
\hline 10 & $\begin{array}{l}\text { My manager is uninterested in important moments (birth, } \\
\text { marriage, retirement, death) of employees' lives. }\end{array}$ & & & & & \\
\hline 11 & $\begin{array}{l}\text { When it comes to self-interests, my colleagues forget the } \\
\text { favors done for them. }\end{array}$ & & & & & \\
\hline 12 & $\begin{array}{l}\text { My colleagues, whom I like and respect, are not there for } \\
\text { me when I need help. }\end{array}$ & & & & & \\
\hline 13 & My colleagues are uninterested in my health problems. & & & & & \\
\hline 14 & $\begin{array}{l}\text { My colleagues are uninterested in important moments } \\
\text { (birth, marriage, retirement, death) of my life. }\end{array}$ & & & & & \\
\hline 15 & $\begin{array}{l}\text { When I lose my power and my position, my colleagues } \\
\text { distance themselves from me. }\end{array}$ & & & & & \\
\hline 16 & $\begin{array}{l}\text { Assistance and services that I provide to my colleagues are } \\
\text { ignored. }\end{array}$ & & & & & \\
\hline 17 & My colleagues quickly forget the favors. & & & & & \\
\hline 18 & Friendship and amity lasts until the work is finished. & & & & & \\
\hline 19 & When I fail, my colleagues do not stand by me. & & & & & \\
\hline 20 & $\begin{array}{l}\text { I help my colleagues all the time, but when I don't once in } \\
\text { a while, they distance themselves from me. }\end{array}$ & & & & & \\
\hline 21 & My colleagues call me only when they need me. & & & & & \\
\hline
\end{tabular}

*1-10 Items: Manager Disloyalty, 11-21 Items: Colleague Disloyalty 